\title{
Spontaneous intercalary scleromalacia
}

\section{Escleromalacia intercalar espontánea bilateral}

\author{
Carmen Alba-Linero*, M. Teresa Sainz-de la Maza, Víctor Llorenç-Belles and Alfredo Adán-Civera \\ Department of Ophthalmology, Hospital Clínic, Barcelona, Spain
}

\begin{abstract}
Objective: To describe a case of spontaneous intercalary scleromalacia with anterior segment photographs and optical coherence tomography. Methods: A 32-year-old woman attended our ophthalmology department due to progressive bilateral epiphora. Anterior segment photographs, optical coherence tomography and topography were performed, as well as a complete blood count with autoimmunity markers. Results: Anterior segment photographs showed absence of limbal vasculature with scleral thinning and bluish discoloration due to visualization of underlying choroidal tissue. Anterior segment OCT confirmed scleral thinning and microperforations. Topographies and blood tests were normal. Conclusion: Spontaneous intercalary scleromalacia is a rare disorder that consists in progressive scleral thinning with microperforation. The presentation of this disorder varies from asymptomatic to extrusion of ocular contents.
\end{abstract}

Key words: Scleromalacia. Scleral microperforation. Amniotic membrane transplantation.

\section{Resumen}

Objetivo: Describir un caso clínico de escleromalacia intercalar espontánea a través de fotografías del polo anterior y tomografía de coherencia óptica (OCT) del segmento anterior. Métodos: Una paciente de 32 años consultó por epífora bilateral progresiva. Se le realizaron fotografías, OCT del segmento anterior y topografías de ambos ojos, así como examen sistémico y analítica sanguínea con perfil de autoinmunidad. Resultados: Las fotografías mostraban la ausencia de vascularización límbica con adelgazamiento escleral y coloración azulada por impronta del tejido coroideo. La OCT del segmento anterior revelaba el adelgazamiento escleral con microperforación del mismo. Las topografías y la analítica sanguínea resultaron sin hallazgos significativos. Conclusion: La escleromalacia intercalar espontánea es un raro trastorno que consiste en el adelgazamiento escleral progresivo con microperforación del tejido. Diversos grados de esta enfermedad pueden variar entre cuadros asintomáticos o extrusión del contenido ocular.

Palabras clave: Escleromalacia. Microperforación escleral. Trasplante de membrana amniótica. 


\section{Introduction}

Spontaneous scleral intercalary perforation is a rare scleral disorder characterized by progressive scleral thinning with spontaneous perforation not associated with other systemic or ocular diseases, or previous trauma.

This lesion can often go unnoticed by being asymptomatic or having imperceptible microperforations. Sometimes, it can be diagnosed after a long history of epiphora or due to hypotonic maculopathy ${ }^{1}$.

A systemic study must always be performed to rule out infectious or autoimmune diseases.

The management of intercalary scleromalacia ranges from observation in milder cases to coating with a scleral patch or amniotic membrane in more severe cases $^{2}$.

Close follow-up is necessary through photographs, optical coherence tomography (OCT) of the anterior segment and magnetic resonance imaging ${ }^{1}$.

\section{Clinical case}

A 32-year-old female patient came to the office after noticing a blister in the conjunctiva of both eyes, accompanied by epiphora. She had no relevant systemic or ocular history. She reported having these lesions for more than 1 year, although she noted worsening of the condition after delivery of a child five months ago.

She had a visual acuity of 0.8 in the right eye (OD) and 0.7 in the left eye $(\mathrm{OI})$ with the following correction: OD: $-6.25=-1.00 \times 70^{\circ}$ and OI: $-5.50=-2.00 \times 130^{\circ}$.

Slit-lamp examination showed absence of limbal vascularization $360^{\circ}$ and perilimbal scleral thinning, with fluid accumulation in the perilimbal subconjunctival space of both eyes. There was also a bluish coloration due to choroidal tissue visualization by transillumination, as well as a mild papillary reaction in the tarsal conjunctiva (Figs. 1 and 2).

Topography showed regular parameters with againstthe-rule astigmatism and a pachymetry of 531 microns and 542 microns, respectively.

Anterior-segment OCT showed a conjunctival bleb with underlying fluid due to scleral microperforation with tissue thinning. Complete blood exams were performed, which only showed a mild eosinophilia (600/microliter). The autoimmune profile (antinuclear antibodies, anti-neutrophil cytoplasmic antibodies, complement factors, erythrocyte sedimentation rate), blood count and biochemistry were normal (Figs. 3 and 4).

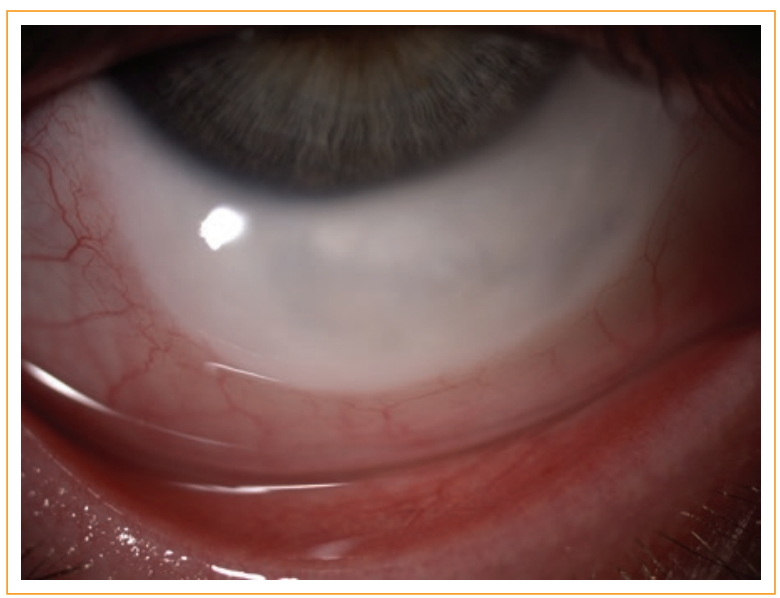

Figure 1. Photograph of the anterior segment of the right eye showing scleral thinning and the absence of limbal vasculature.

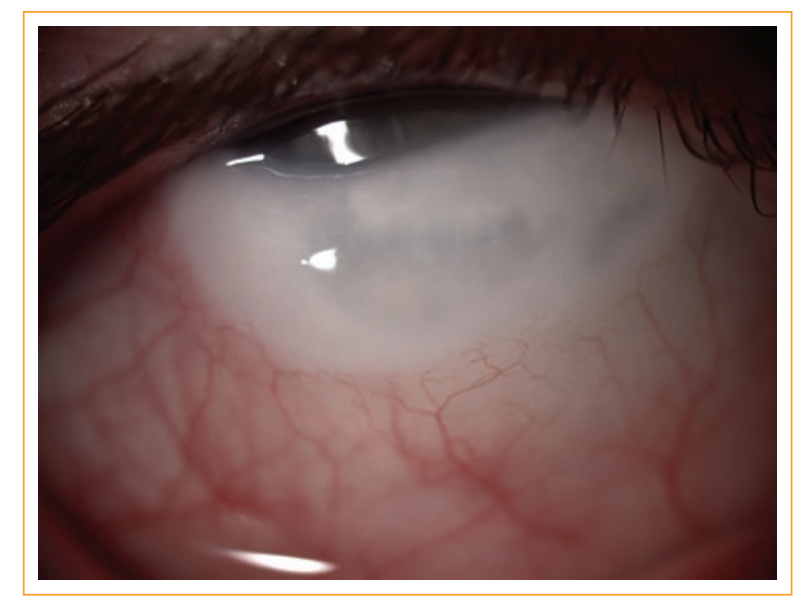

Figure 2. Photograph of the anterior segment of the left eye showing scleral thinning and absence of limbal vasculature, as well as a bluish reflex due to visible choroid.

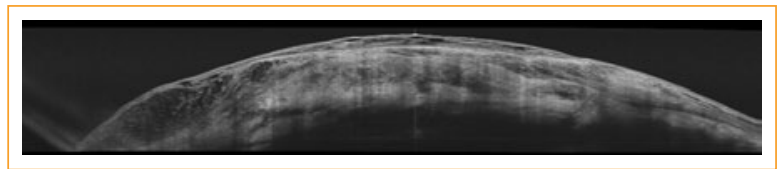

Figure 3. Optical coherence tomography of the anterior segment of the right eye revealing scleral thinning and tissue microperforation.

Given the stability of the signs and symptoms in several consecutive visits, the surgical alternative (scleral versus amniotic membrane patch) was discarded, and we decided to observe the patient with OCT monitoring. 


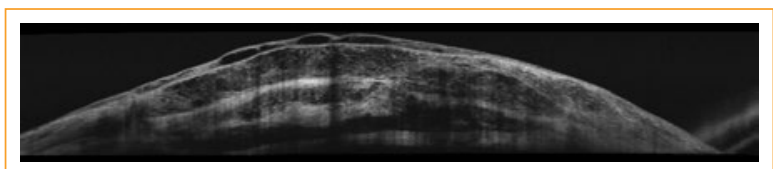

Figure 4. Optical coherence tomography of the anterior segment of the right eye revealing scleral thinning and tissue microperforation.

\section{Discussion}

The sclera maintains and protects the ocular structures and, despite not having a role in visual processing, the diseases that affect it such as scleritis, scleral perforations or pathological myopia pose a therapeutic challenge in ophthalmology.

Scleral tissue comes from the mesoderm and has chondrogenic potential; this explains why it constitutes a target for autoimmune diseases, sharing this characteristic with joint tissue ${ }^{3}$; likewise, the conformation of the deep scleral plexus also contributes to scleral tissue affectation in immune disorders.

Intercalary scleromalacia can often lead to spontaneous perforation of the eyeball, with subsequent choroidal prolapse $e^{4,5}$. This is an ocular emergency that must be resolved with surgery within the first 24 hours. Patients should also be advised to avoid contact sports and situations that carry a risk of eye trauma, given the susceptibility of scleral tissue. Some theories establish that this disease may belong to the group of ocular colobomas ${ }^{6}$ and that it is secondary to an alteration of the scleral collagen detected by histopathological examination?

\section{Conclusion}

Given that this rare entity does not have an inflammatory origin, the use of classic or biological immunosuppressants is not useful for its management, as could be the case in other scleral diseases, so the management of complications from spontaneous intercalary scleral perforation has to be surgical.

\section{Conflicts of interest}

The authors declare no conflicts of interest.

\section{Ethical disclosures}

Protection of human and animal subjects. The authors declare that the procedures followed were in accordance with the regulations of the relevant clinical research ethics committee and with those of the Code of Ethics of the World Medical Association (Declaration of Helsinki).

Confidentiality of data. The authors declare that they have followed the protocols of their work center on the publication of patient data.

Right to privacy and informed consent. The authors have obtained the written informed consent of the patients or subjects mentioned in the article. The corresponding author is in possession of this document.

\section{References}

1. Gaucher D, Ballonzoli L, Saleh M, Sauer A, Bourcier T, Speeg-Schatz C. Spontaneous scleral rupture revealed by hypotony maculopathy. 2009;32,6:438.

2. Ma DH, Wang SF, Su WY, Tsai RJ. Amniotic membrane graft for the management of scleral melting and corneal perforation in recalcitrant infectious scleral and corneoscleral ulcers. Cornea. 2002; 21(3):275-83.

3. Seko Y, Azuma N, Takahashi Y, Makino H, Morito T, Muneta T, et al. Human Sclera Maintains Common Characteristics with Cartilage throughout Evolution. PLoS ONE. 2009,3:125-32.

4. Cappin JM, Allen DW. Paralimbic scleromalacia Spontaneous scleral intercalary perforation. Brit. Ophthal. 1973;57:871.

5. Turaga K, Senthil S, Jalali S. Recurrent spontaneous scleral rupture in Marfan's syndrome. BMJ Case Rep. 2016; 2016. pii: bcr2016214764.

6. Fernández López E, Poon A, Huhtanen A, Lindsay R, Green C. Bilateral Blebs Secondary to Spontaneous Scleral Perforations. J Glaucoma. 2017;26,6:177-9.

7. Sorensen TB. Paralimbal scleromalacia. Socalled spontaneous scleral intercalary perforation. Acta Ophthalmol (Copenh). 1975;53,6:901-7. 